\title{
EDITORIAL
}

Roger Miarka ${ }^{*}$

\section{O que pode um Editorial?}

O que pode um editorial?

Esse verbo - poder - é um tanto quanto ambíguo. Por um lado, "poder" diz da permissão para fazer; por outro lado, diz da potência do fazer. Podemos, porque nos é permitido. Podemos, porque temos potência.

O que pode um editorial?

Pode dizer dos artigos que veicula, entendidos um a um, ou em pequenos grupos temáticos. Nessa edição 52, temos textos que falam de História da Matemática, de Etnomatemática, de Modelagem Matemática, de Ensino e Aprendizagem, de Formação de Professores, de Atividades centradas em objetos matemáticos específicos, de Filosofia da Matemática...

Esses temas, que frequentemente se sobrepõem - e cujos artigos poderiam ser categorizados das mais diversas maneiras -, apresentam a diversidade de nossa área quando entendidos como grupos de interesse, mas também quando olhados um a um. São compostos por textos que atravessam a Educação Matemática e suas tendências. A cada travessia, uma nova Educação Matemática se faz. A cada nova Educação Matemática, um novo mundo se abre com espaço para novas pesquisas e outras travessias.

Nesse movimento, a Educação Matemática brasileira tem se mostrado com muita força, criativa e sólida, destacando-se no panorama internacional, fruto da seriedade e esforços de pesquisadores que o BOLEMA tem a oportunidade de acompanhar há trinta anos.

O que mais pode um editorial?

Também pode dizer dos artigos que circula compreendidos como um conjunto, ou melhor, como uma rede que diz de uma área.

O BOLEMA veicula artigos de pesquisa em Educação Matemática. Não se trata apenas de um espaço para publicação. Ele reúne artigos, ele diz de tendências, ele fala de um panorama da

"Doutor em Educação Matemática pela Universidade Estadual Paulista Júlio de Mesquita Filho, Brasil. Professor Assistente Doutor e Pesquisador da Universidade Estadual Paulista Júlio de Mesquita Filho, Brasil. Endereço para correspondência: Av. 24-A, 1515 - Caixa Postal 178 - CEP: 13506900 - Rio Claro, SP, Brasil. Email: romiarka@gmail.com 
pesquisa em Educação Matemática. Ele discorre sobre a pesquisa como um todo. Ao mesmo tempo em que a alimenta, por ela é alimentado.

O que, então, pode um editorial?

Pode dizer da situação daquela que o alimenta.

Há pouco mais de dois meses, as universidades brasileiras receberam um comunicado da Coordenação de Aperfeiçoamento de Pessoal de Nível Superior (CAPES), informando-as de um corte drástico - algo em torno de $70 \%$ - da verba do Programa de Apoio à PósGraduação (PROAP) e do Programa de Excelência Acadêmica (PROEX).

É importante destacar que esses programas são instrumentos básicos de financiamento das pós-graduações no Brasil. Em especial, na Educação Matemática, em que não temos grandes investimentos empresariais - uma vez que o retorno de nossas pesquisas não visam ao lucro -, esses dois Programas constituem praticamente todo o respaldo financeiro que temos.

Um corte como este não ajusta o financiamento a uma situação orçamentária, mas inviabiliza o funcionamento de nossos programas de pós-graduação, em que, majoritariamente, nossa pesquisa é produzida.

Vemos com preocupação que o projeto "pesquisa" desenhado com expectativa e sabedoria desde a década de 1950 está se desfazendo. As agências fomentadoras de pesquisa como CNPq, FAPESP e, mais recentemente, a CAPES, e demais FAPs - estão carentes de recursos, a ponto de não mais fomentarem a pesquisa como esperado. Os pesquisadores em ação já estão sentindo essa carência. Perguntamos: permanecerão até quando entre nós? E de que modo essa situação incidirá sobre os pesquisadores ainda em formação?

O BOLEMA ainda não sentiu essa crise. Ainda não perdeu suas (poucas) fontes de financiamento e neste ano ainda recebeu submissões anuais na ordem da centena. Em suma, ainda tem seu alimento. Ainda tem seu espaço. No entanto, bem sabemos que a fome não surge quando a comida se esgota, mas quando o corpo começa a reclamar.

O que ainda pode um editorial?

Um editorial ainda pode dizer de uma situação calamitosa que sofre a pesquisa e a pós-graduação brasileira, como um apelo às políticas que regem os financiamentos, para que tomem seriamente a pesquisa brasileira em sua especificidade de modo atento às suas necessidades.

Não contamos com verbas de doação à moda de outros países. Não possuímos em nossa equipe editorial profissionais específicos e remunerados para as funções que lhes cabem. Somos "também" diretores executivos. Somos "também" editores. Somos "também" pareceristas. Somos "também" professores. Somos "também" educadores. Somos "também" gestores. Somos "também" pesquisadores. Somos "também" muitas outras coisas, que acabam ficando esquecidas em meio a tantos "tambéns". 
Qual é a distância entre o "também", o "ainda" e a morte, da pesquisa, de uma revista, ou de uma área?

Com um pouco de medo da resposta, nos perguntamos: $O$ que pode um editorial? 